\title{
IRONY AND INTERTEXTUALITY IN CAT CITY
}

\author{
ANITA DEÁK \\ Babeș-Bolyai University \\ deak.anita89@gmail.com
}

\begin{abstract}
Most Hungarian cartoons were meant for the whole family rather than just children. Due to this fact, everyone could enjoy the stories, the little ones loved the animal characters, which were often in the center, and the adults could laugh at the ironic and caricaturistic situations and representations. In my research I analyze the hidden meanings of a classic Hungarian cartoon entitled Cat City, brought up through intertextuality, allegory, irony and other rhetorical devices that might communicate an underlying meaning. I also examine the kinds of television tropes and archetypical characters that are likely to appear in the cartoon. The cartoon's main situation is the fight between cats and mice, and it is a parody of several famous feature films, focusing mainly on the James Bond series. The main plot is about a special spy who is sent to the city of "Pokyo" to get the secret plan for a machine which could save the mouse civilization. These underlying meanings greatly added to the Hungarian cartoon's popularity, which sometimes represented the symbols and even flaws of the communist system.
\end{abstract}

Keywords: irony, intertextuality, popularity, Cat City, Hungarian animation

\section{Introduction}

Even though nowadays the Hungarian animation factory isn't in the best shape, there were times when the Pannonia Studio was one of the five most successful studios in the world, alongside Walt Disney, Hanna-Barbera, Soyuzmultfilm, and Toei. The studio's best period was between 1980 and 1986. During this period it produced the most movie cartoons, and the era was known as the golden age of Hungarian animation film. The period was successful not only for the high number of cartoons created but they were great in quality as well, they even got several prizes from different countries around the world. Caricature and humor were always important parts of the Hungarian cartoons, but in the 1960s they begin to follow new guidelines and deal with important ethical, social or economic problems. In a way the cartoons become social mirrors to the viewers. In this period next to the children cartoons they made many animations for the adult audience too, but the most popular pieces where those for the entire family. These family cartoons usually had animal characters or at least animal sidekicks. Due to the ironic and caricaturistic representations and underlying meanings, adults were also huge fans. 


\section{About the research project}

In my $\mathrm{PhD}$ research, I analyze these underlying meanings and comical representations, and the current article examines one of the most popular Hungarian family cartoons, Cat City, from this perspective. Cat City was made in 1986, and it still has many fans. In 2007 they even made a sequel to it. What rhetorical devices were used in Cat City to communicate its deeper meanings, like irony, intertextuality, allegory, and what exactly was the message behind all this? Also, what kinds of television tropes are represented by the characters? In this essay, I address these questions.

According to my hypothesis, irony, intertextuality and hidden representations of society were the key to the popularity of these cartoons, as is the case today in popular American animation films. In my textual analysis, I use multiple methods, since I want to draw out latent themes within the text and make connections between them. In my assessment, the combined use of content analysis and semiotics is the best way to figure out the themes and issues in the media text.

The importance of my research is that media texts are parts of our lives, and by studying them, we can get a deeper understanding of certain cultures and how the different meanings and messages are created.

More or less every media text is permeated with intermedia and intertextuality, and the importance of these is greatly increased in situations in which free speech is forbidden, or at least censored carefully. This was the situation in Hungary and the neighboring countries when the animation film on which I am focusing were made. At the time, television and radio stations were in a monopoly situation, where both were in the hands of the state and they were mostly used for propaganda purposes, like other art forms in general. (Urbán 2005)

One of the premises of my paper is the realization of the importance of the recipients own experience and knowledge in order to interpret the true meanings of the cartoons. As Magdolna Orosz (2003) says, texts are truly expansible with an intertextuality research, but in order to do that you need serious background knowledge.

Considering that the cartoon I'm analyzing is audiovisual in its contents, I separate two types of intertextuality, namely verbal and visual intertextuality, to discover which is more preferable in the cartoon.

Irony is harder to define. It isn't enough just to look it up in a dictionary. Irony is a much more complex and confusing thing if we try to capture its true meanings and implications. Even in dictionaries one finds multiple explanations of it. "Irony has a hierarchical dimension, excluding some members of the audience from its 'other' or implied sense" (Greene et al. 2012, 732-735). Usually it is defined as an expression or utterance, marked by a deliberate contrast between apparent, intended meanings and a literary style, employing contrasts for humor- 
ous or rhetorical effects. Many times it is also defined as an incongruity between what might be expected and what actually occurs. This last definition actually emerged from the misuse of irony. People began to use irony to describe situations which are simply unfortunate rather than ironic. In time this misuse of irony became a secondary explanation of the term, and it is called situational irony or cosmic irony, which is used to describe situations in which God or Fate is playing games with the characters, for example Murphy's Law.

Usually we are speaking about three types of irony: verbal (a use of words to mean something different than the person actually says, and it's always intentional by the speaker), situational (when fate is playing with the characters and the exact opposite of what is meant to happen, happens) and dramatic (when the audience knows more than the characters). On the other hand, the fourth edition of Princeton Encyclopedia of Poetry and Poetics distinguishes seven types of irony. For my current article I will use the three more commonly known types.

\section{The history of Hungarian animation}

Media products usually represent the current needs of society, and thus their importance stops in the present. Due to the cultural and social references these products contain, a historical analysis could provide interesting information. These stories represent what's important for the audience, what's good or bad, what the current pop culture is built on. All of these media products, in a way, represent their audience's needs and tastes. (Angelusz et al., 2007)

Of course, in the research on the golden era of Hungarian animation films, we can't forget that these stories were made during communism, and even though at the time in Hungary there was only a softer type of dictatorship, which was more ready to compromise, media and art were still under the influence of the state.

In the late Kádár era, both, the Soviet media policy and the domestic media policy can be detected simultaneously in a changing social environment, because the regime began to face a deepening crisis in the 1980s. The state interfered less often and less aggressively with works of media, but still, even entertainment topics were politicized and everything was supposed to promote the state ideology. They loved to use the tools of propaganda to create images of enemies and depict a bipolar world and stereotypes. (Bajomi 2005)

The dawn of Hungarian animation is somewhere in the 1930s though there were attempts even before that. At the beginning they were making mostly advertisements with different animation techniques, but some of these were so sophisticated with such nice stories, that they could have been accepted as standalone animation films as well. Unfortunately the animators didn't get any other possibility in the country besides the advertisements, so most of them chose to 
emigrate to the west. Cartoon making kicked off after the Second World War and the nationalization of the film industry, but even then they could only make maximum one cartoon per year.

The renaissance of the Hungarian animation industry came in the 1960s, when cartoons got renewed in both form and content. In this era caricature became one of the main tools used in the animation, and beyond children stories they began to represent the real problems of society and everyday life. Also in this time period the dominant genre were the serials.

In the 1980 s, Hungarian animations reached their peak, most of the bibliography calls the 1980-1986 period as the Golden Age, because they made the most animation movies in this period, twelve movies in total, and in 1981 they even won an Academy Award in the animated short category with the Fly. Unfortunately, after the golden age the Hungarian animation industry began to fall, though they still exist today in different forms, the industry's glory never returned.

\section{Cat City}

The animated film Cat City was released in 1986, and it was one of the fifth biggest blockbusters of the 1980s in Hungary (http://imdb.com). It was made in the Pannónia Film Studio, which worked together with the Hungarian national television. At the time this was the only television channel in the country. Cat City was directed by Béla Ternovszky, and the script was written by József Nepp, who was well known for his particular sense of humor and his stories, which were always full of puns. The cartoon was not only popular in Hungary but abroad as well. It was even selected as the Hungarian entry for the Best Foreign Language Film at the 59th Academy Awards, but at the end was not accepted as a nominee.

The target audience was not specified. The film was screened without a parental guide and it was probably for intended as family entertainment, like most of the other animation movies. While the little ones could enjoy the cute animal characters, the story which was filled with intertextuality and ironic humor was more for the adult audience who already have some lexical and film history knowledge. The cartoon is mostly filled with movie references, but we can find jazz song adaptations too. It is a little known fun fact, for example, that the cartoon was based on the song Four Brothers by Manhattan Transfer, which was one of József Nepp's favorite bands. In the cartoon, the adaptation of this song became the song of the four rats.

The cartoon's cat and mouse game is mostly a parody of several famous western feature film and contains classic characters from these films, most of them coming from the James Bond franchise, but almost everything that was part of 1980s pop culture can be found in the film. Even the first frame is a reference 
to Gongman, the logo of the British Rank Organization, only in the cartoon it is represented by a cat gong and a mouse. After the Gongman imitation the movie opens with a Star Wars style text scroll which tells us the main situation of the story: "In the year 80 AM (Anno Mickey Mouse), the mice of Planet X are threatened by humiliation and total apocalypse. The well-organized, fully equipped gangs of evil cats are aiming to wipe out the mouse civilization totally, not caring for the old conventions between mice and cats. But in the last moment, when the mouse leaders are beginning to consider leaving the planet, a new hope rises..."

Even though the story is placed on the fictional X planet, the main locations are easily identifiable in the real world. The first metropolis we see is definitely symbolizing the big cities of the US, and most of the mice have at least partly English names. There are some Russian ones too, which makes us associate these things with the "good ones". In addition to the urban settings that resemble Western cities, other sites appear too, for example the jungle area where Lazy Dick crashes is similar to Central America around the Amazon. For the secret weapon plans the protagonist travels to a very stereotyped version of Tokyo called Pokyo.

The cartoon uses an alternative timeline: 80 Anno Mickey Mouse, which contains elements from the 1940 s or 1950 s swing style to the 1980s pop culture and political situations. It also has a science fiction feeling which was not common in the Hungarian movie industry at the time. Alternative or made-up timelines are pretty commonplace in the cartoon industry, because this way it's easier to give a timeless meaning to the story or in certain situations to mask the underlying meanings. The bipolar world of Cat City, with their secret super weapons for example, greatly resembles the Cold War threats, the arms race or the experiments in different areas.

The scene containing the title can be interpreted as an allegory. The cityscape first seems futuristic, yet as the sun rises the buildings are somewhat similar to those built in the time of communism. Even the appearing Cat City title is, in a way, like a communist version of the Hollywood sign, with full red color and red reflectors with the rising sun.

All the characters in the cartoon are well known movie tropes, so it's not surprising that the opposing sides are cats and mice, whose fight is a well-established storytelling strategy, like the sides they represent. Mice are usually small, weak and innocent characters, but also smart, kindhearted and heroic. In contrast, cats are represented as evil and manipulative creatures who oppress and torture the weaker just for fun. This story trope can be traced back for a number of reasons: the independence and stubbornness of cats, which is seen by many as a negative trait (as is the fact that they like to hunt for fun), though the negative representation of the poor creatures goes back to the Middle Ages, when they were associated with witches. 
The cartoon's protagonist is Nick Grabovski, a retired mouse super spy, who got tired of his job and now lives in a secluded little house. He wears a red and blue t-shirt with a big yellow $\mathrm{G}$ on the front, being a drawn metaphor of Superman, but as the story goes on he also represents some James Bond personality traits. Without doubt he is the story's ace character, the legendary super-agent with super mouse abilities. Yet we don't meet him right at the beginning of the film. For a while, we only hear about his reputation, and we learn that nowadays he is retired and reads Thoreau. The mention of Henry David Thoreau in a communist family cartoon is certainly an interesting detail, considering that Thoreau is mainly known for his essay Civil Disobedience, an argument for disobedience to an unjust state. Unlike the communist rulers, our ace protagonist has a weakness, much like James Bond, he has a soft spot for the other gender and when he meets Chino San, he begins to put her safety first, thus losing his focus, which leads to both of them being captured. This makes him seem more human.

As Grabovski's counterpole stands Sergeant Lazy Dick, who is a very optimistic and kind mouse, but who is fat and not so smart. He is sent on a mission as bait, to divert attention from Grabovski. He mostly represents the unfortunate common folk, who are often the victims of tragic irony, but at the end of the day he saves everyone, despite his clumsiness.

In the evil cat party, the more important character tropes include, for example, Mr. Fritz Teufel. Teufel is kind of a CEO among the cats. His name in Hungarian sounds like the word "tejföl," or sour cream, while in German it means devil, and he shares the name with a German activist from the 1960s, who was a Spaßguerilla member and was protesting for social change, liberalism, and in support of a less materialistic society. In the cartoon, Teufel resembles the bad boss trope, and like many other evil characters in different stories, he has physical defects. For the sake of comical impact these defects are strongly exaggerated. He also smokes, which is usually associated only with the bad guys in cartoons.

The head of the whole cat syndicate is Giovanni Gatto, a white Persian cat, who is a clear reference to Blofeld from James Bond. The only exception under the evil cat trope is Cathy, who is depicted as the innocent child, who is often in detention because she's making friends with mice. In addition, there are plenty of other interesting characters who also represent classic movie tropes and stereotypes. The four gangster rats represent some common stereotypes, and the composition of their team was very popular in the American movie narratives at the time. Their leader is Buddy, who has anger management issues. Billy, who isn't the smartest rat in town, is usually the target of Buddy's anger. The two women characters from the team represent a big contrast: Pissy is a black haired, cold but smart and professional girl, while Cookie is blond and simple-minded with loose morals. The damsel in distress character is represented by Chino San, who of course ends up with our protagonist. 
In this short article it's unnecessary to analyze the whole cartoon, though I would like to highlight some moments from the beginning of the story to exemplify how irony and intertextuality are used in Cat City.

In the first scene of the story we see the mouse bank and we hear a desperate conversation between an employee and a customer about how nowadays cats can get in everywhere and loot their treasures. The bank employee tries to convince the lady that their bank is absolutely cat proof unless they come with a tank. And we see cosmic irony at its best when the cats immediately break into the bank with a tank. As a response to this, the bank employee yells over my dead body, and again immediately he gets shot by the tank. Finally the scene ends with the incompetent mouse police force, which isn't surprising. Postmodern artists always loved to make fun of the authorities.

Hereinafter we can see the story from multiple characters perspective. The main plot is about the search for the anti-cat super weapon. Most of the characters take part in this, but in some side plots we can get a better grip of what the world of the cartoon looks like, and how the characters live. For example, the cats are trying to get into the mouse holes and steal their cheese.

Shortly after the bank robbery scene we meet with the cat party, including Teufel, who is kind of the story's Darth Vader. He chokes his employee with cigar smoke rings instead of the Force. His assistant Safranek, a red headed cat, is maybe the least evil from the syndicate, but he is the constant target of Teufel's aggressiveness, and he gets beaten up every time something goes awry. We can also see in this scene the cat syndicate's secret experiments. Currently they are trying to miniaturize cats so they can walk in the mouse holes. Teufel, however, quickly recognizes the flaws in the plan. This makes it evident that he is a smart villain. We also get some easily recognizable verbal and visual intertextuality, i.e. a reference to a Tarzan movie.

After we meet the cats and get to know the main situation of the story, the cartoon takes us to the Intermouse, the secret headquarter of the mouse agents. The building is introduced by following a mouse agent, Edlington, through the overcomplicated security procedure he needs to undertake in order to get inside. The security systems resemble the ones we see in spy movies, though in an overdone humorous way (tail prints instead of fingerprints, different kind of laser sensors and radiology screenings, password etc.). But in the form of dramatic irony we soon realize that all the security measures are useless and are only for the illusion of safety, because the cats are listening in. We also get a nice visual intertextuality in the form of the Intermouse table, what can represent both the Knights of the Round Table and a Hungarian cheese product. 


\section{Conclusion}

In general, Cat City is not an ordinary Hungarian cartoon due to all the references to the Western world and its movie industry, but the linguistic humor is quite frequent in their cartoons, and it matches Nepp József's works. Even though Cat City met with some negative criticism because of its Western feeling, it was and still is one of the most popular Hungarian cartoons. That means that even back then there was an attraction to the western world, and this worldview also drew attention to the democratic systems, which might be one of the reasons why the cartoon's script was refused at first by the state. As a cartoon built on Western movie block busters, it didn't contain enough communist propaganda. Of course traces of the symbols and ideas of the regime are noticeable. The stereotypes and bipolar world can be interpreted as both, a common storytelling strategy in the movie industry and also as the leading tools in media politics during the Kádár era.

Leaving politics aside, we can simply get a feel of popular trends and tastes in the 1980s, because almost everything that was representative in the 1980s pop culture can be found in this cartoon. Since it has a bunch of movie tropes and archetypal characters, it can also be interpreted as a caricature of the film industry itself.

Regarding intertextuality, the cartoon mostly uses visual allusions, and these visual references are usually inspired by movies. On the other hand, we can also identify plenty of verbal references too, especially in the Hungarian version. The interesting thing is that the verbal intertextuality is not limited to movies. We find references to mythology, philosophy and even history.

The question of how references stand the test of time is always a concern in the case of a work rich with intertextuality. The film may well have meanings for audiences today which differ considerably from the meanings it had for audiences in the 1980s. Interpretations of the film from the viewpoint of young adults who weren't even alive when the cartoon was made and grow up in a completely different world can hardly be compared to interpretations from the perspective of a view of the 1980s. The movie references mostly stood this test, because there have been innumerable remakes of and variations on the movies to which the cartoon originally alluded, so the genre remains familiar (for example James Bond and Superman movies). The political or social references are harder to catch today.

In the case of irony, we can identify all three types of irony (verbal, situational and dramatic) in the cartoon, though verbal irony is the most common, which isn't surprising, seeing as how this was the easiest form to introduce in the different situations. However, some of the more memorable scenes are built on situational or dramatic irony, which means that the creators didn't have a preferred irony type. Rather, they tried to use as many tools for humor as they could. 


\section{References}

Angelusz, Róbert, Tardos, Róbert and Terestyéni, Tamás, 2007. Média, nyilvánosság, közvélemény. Budapest: Gondolat Kiadó.

Bajomi-Lázár, Péter, 2005. Médiapolitika. In: Bajomi-Lázár, Péter, ed. Magyar médiatörténet a késö Kádár-kortól az ezredfordulóig. Budapest: Akadémiai Kiadó, 19-51.

Barthes, Ronald, 2010. A kép retorikája. In: Blaskó, Ágnes, Margitházi, Beja, ed. Vizuális kommunikáció. Szöveggyüjtemény. Budapest: Typotex, 109-124.

Dizseri, Eszter, 1998. Kockáról kockára (A magyar animáció krónikája 1948-1998). Budapest: Balassi Kiadó.

Greene, Roland, Cushman, Stephen, Cavanagh, Clare, Ramazani, Jahan and Rouzer, Paul 2012, The Princeton Encyclopedia of Poetry and Poetics: Fourth Edition. New Jersey: Princeton University Press.

Hernández, María Lorenzo, 2007. The Double Sense of Animated Images, Animation Studies, 2. [online] Available at: https://journal.animationstudies.org/maria-lorenzo-hernandez-thedouble-sense-of-animated-images/ [Accessed 10 July 2017]

Marghitházi, Orsolya, 2002. A magyar rajzfilmmüvészet. Filmtett. [online] Available at: http:// www.filmtett.ro/cikk/1439/az-animacios-film-tortenete-4-3 [Accessed 10 July 2017].

Orosz, Magdolna, 2003. „Az elbeszélés fonala” - Narráció, intertextualitás, intermedialitás. Budapest: L'Harmattan.

Simon, Éva, 2002. Intertextualitás és struktúra. Palimpszeszt - Tudományos és kulturális folyóirat, 17. [online] Available at: http://magyar-irodalom.elte.hu/palimpszeszt/zemplenyi/45. htm\#fn1 [Accessed 10 July 2017].

Stokes, Jane, 2008. A média és kultúrakutatás gyakorlata. Budapest: Gondolat Kiadó.

Szilvássy, Orsolya, 2012. Üzenet a múltból és a jövöböl. in Médiakutató, 4. [online] Available at: http://www.mediakutato.hu/cikk/2012_04_tel/09_uzenet_a_multbol [Accessed 10 July 2017].

Urbán, Ágnes, 2005. Rádió és televízió. In: Bajomi-Lázár, Péter, ed. Magyar médiatörténet a késő Kádár-kortól az ezredfordulóig. Budapest: Akadémiai Kiadó, 89-111. 